\title{
Algorithmic Thinking as the Meaningful Component of Cognitive Competencies of the Future Engineer
}

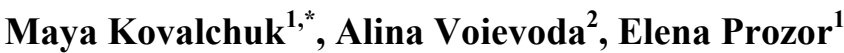 \\ ${ }^{1}$ Department of Higher Mathematics, Vinnytsia National Technical University, 21020, Vinnytsia, Ukraine \\ ${ }^{2}$ Department of Algebra and Mathematics Teaching Methods, Vinnytsia Mykhailo Kotsiubynskyi State Pedagogical University, 21020 , \\ Vinnytsia, Ukraine
}

Received July 30, 2020; Revised October 8, 2020; Accepted October 19, 2020

\section{Cite This Paper in the following Citation Styles}

(a): [1] Maya Kovalchuk, Alina Voievoda, Elena Prozor, "Algorithmic Thinking as the Meaningful Component of Cognitive Competencies of the Future Engineer, "Universal Journal of Educational Research, Vol. 8, No. 11B, pp. 6248 6255, 2020. DOI: 10.13189/ujer.2020.082263.

(b): Maya Kovalchuk, Alina Voievoda, Elena Prozor (2020). Algorithmic Thinking as the Meaningful Component of Cognitive Competencies of the Future Engineer. Universal Journal of Educational Research, 8(11B), 6248 - 6255. DOI: 10.13189/ujer.2020.082263.

Copyright $\bigcirc 2020$ by authors, all rights reserved. Authors agree that this article remains permanently open access under the terms of the Creative Commons Attribution License 4.0 International License

\begin{abstract}
The given paper contains the explanation of the importance of algorithmic thinking development and introduces the idea of special formation of the operational components of this thinking in order to improve the mastering of the educational actions in the sphere of mathematics. The research describes certain specific features of studying higher mathematics at Technical Universities. The aim of the research is to determine experimentally and substantiate the impact of the development of algorithmic thinking components on the level of mathematical knowledge and skills formation. On the base of Vinnytsia National Technical University in 2017, 2018, 2019 the experiment was carried out, it consisted of two stages: exploratory stage and formative stage. We responded 275 students. Main conclusions: the problem of algorithmic thinking formation of schoolchildren and students is generally recognized in the world; only a small number of students are able to apply the operational components of algorithmic thinking comprehensively in a holistic process of solving various problems, manage their mental activity consciously and think logically; if students develop techniques of mental actions, which are the main components of algorithmic thinking (the ability to generalize, classify, draw analogies, establish patterns and reason logically), it contributes to better learning of higher mathematics.
\end{abstract}

Keywords Algorithmic Activity, Algorithmic Thinking, Operation Components, Sequence of Actions.

\section{Introduction}

Professional training of future engineers in the field of electric power engineering, electric engineering and electrical mechanics is based on the standard of the higher education (2019), which provides the organization of the educational process, applying the advanced concepts of the integrated education, efficient correlation of theoretical and practical components, maximal usage of the possibilities of computer technologies. Accordingly, the formation of the algorithmic thinking occupies an important place in the process of future engineers training, the need of such thinking for the specialists of various fields is generally recognized.

Various content aspects of the algorithmic thinking are considered in the methodical literature: ways of the algorithmic thinking formation by means of the systematic and purposeful implementation of the ideas of the structural approach (Gejn, 2003; Nikolaeva, 2020; Jurkov, 2019); various structural components of the algorithmic thinking and their adaptation to different subject (Ershov, Zvenigorodskij \& Pervin, 1979; Smetanina, 2010; Gubina, 2016); some aspects the educational process optimization which promote the development of the algorithmic thinking and its connection with other types of thinking (Milkova, 2014; J. Gal-Ezer \& G. Zwas, 1996); scientific 
research of the impact of the algorithmic activity on the formation of the intelligent operations Altuhova \& Smirnov,2016; Kalitina, Pushkareva \& Stepanova 2015 Kalitina, Pushkareva \& Stepanova 2017; Spirin, \& Vakaliuk, 2017).

For instance A. Ershov (1979) defines the algorithmic thinking as "the ability to plan the structure of actions, necessary for achieving the goal, by means of the fixed set of tools".

The possibilities of training future teachers of mathematics to develop in pupils the creative and algorithmic thinking are elaborated in the studies of $\mathrm{K}$. Vlasenko, V. Achkan, I. Lovianova (2020).

Means of the development of critical and algorithmic thinking are considered in the studies of Kurnia Fermani Hidayah, Suparman, Yahya Hairun, Diah Prawitha Sari (2020).

Technological aspects of the modern concept of the algorithmic thinking formation T. Bell and F. Rosamond (2016) considered in the context in mathematical subjects teaching and application of the elements of situational games.

J. Hromkovič and T. Kohn (2016) determined the basic aspects of the algorithmic thinking in the process of research activity as the goal of education programs realization: notion of the formal language for the expression of the algorithms, abstraction and automation in order to transfer the verified strategy to new cases.

A. Wilson and S. Golonka [2013], regard the specific examples of the algorithms application in the life of a human being (algorithms of motion, algorithms of the action choice, hybrid algorithms, etc.). The scientists note, that in the process of life activity there exists so-called "internal algorithms", which control time and scale of human being behavior in the environment.

In the developed countries of the world considerable changes in the content of mathematics syllabuses for different levels of study take place. Ministry of Education of the United Kingdom in 2016 introduced new educational curricula on mathematics for the school children at all the levels of education. They include logic, algorithms and data presentation (Program of Study, 2016). In France, new national education program - "Algorithmique et programmation" (Ministere de l'Education Nationale, 2016) for all the education levels, that comprises algorithmic thinking and computational concepts is created.

Since 2020 Ministry of Education, Culture, Sports, Science and Technology of Japan (MEXT, 2018) plans to introduce the algorithms and computer programming as the obligatory subject for all the pupils of the primary school.

In case of Japan the press release with the information concerning the official inclusion of the computer programming in the school program was made on behalf of the three Government Ministries of Japan: Ministry of Education, Culture, Sports, Science and Technologies
(MEXT, 2018), Ministry of Interior Affairs and Communications (MIC) and Ministry of Economics, Trade and Industry (METI).

In Australia, National Education Plan (ACARA, 2016) now contains such subject as digital technologies (Stephens, 2018). Commenting the inclusion of the digital technologies into Australian education plan, the well-known Australian scientist D. Clark notes that for the greater part of teachers the content of this subject will be complicated problem, as it requires to teach pupils algorithmic thinking.

Thus, the problem of the formation of algorithmic thinking of the pupils and students is generally accepted in the world.

In this study, we observed whether the purposeful development of students' mental actions, which are the main components of algorithmic thinking (the ability to generalize, classify, draw analogies, establish patterns and think logically), promotes better mastery of knowledge in higher mathematics.

\section{Materials and Methods}

\subsection{Materials}

We conducted research and synthesized the meaning of the concept of "algorithmic thinking", identified its semantic characteristics that would meet the purpose of this study. Under algorithmic thinking we will understand a set of mental actions, techniques and forms that provide results in a formalized (algorithmic) form.

Algorithmic thought processes are provided by a set of certain mental actions. The main role is played by generalizations, classification, analogy, establishment of regularities and logical reasoning. The result of algorithmic activity is the formation of appropriate algorithmic skills.

Systematizing the meaning of the concept of "algorithmic thinking", we identified the skills of students that can be formed through their development, adapting them to the discipline of "higher mathematics". These are the skills: to analyze the initial data and determine the results; to find the sequence of actions that are necessary to solve the problem; to allocate in the general task a number of simpler tasks; to construct schemes of vision of the problem as a whole; to solve problems in large blocks with further detailed elaboration; to think inductively and deductively; to write a computer algorithm for solving a problem.

Algorithmic thinking is a significant component of the cognitive key competencies of the future technical engineer. The developed algorithmic activity allows students to effectively structure and systematize new knowledge, and this improves the process of forming special knowledge of the future specialist. Only having a systematic basic knowledge, you can master the system of 
special knowledge.

\subsection{Methods}

In our study, we improved students' ability to generalize, classify, draw analogies, establish patterns and think logically, and observed how this affects the level of formation of mathematical knowledge and skills.

The research was conducted at Vinnytsia National Technical University for three years $(2017,2018,2019)$ during classes and classes-consultations in higher mathematics at the Faculty of Electric Power Engineering, Electrical Engineering and Electromechanics. Over a period of three years, the experiment covered 275 students.

Experimental research can be divided into four stages, each of which conducts some research work with specific tasks.

The first stage. The analysis of literature on the research topic is carried out, the content of the concept "algorithmic thinking" is synthesized, the methods of mental actions which are the basic for this type of thinking are allocated.

The second stage. A method was chosen to improve students' ability to generalize, classify, draw analogies, establish patterns and think logically.

The third stage. The level of formation of selected methods of mental actions and the level of mathematical knowledge formation (low level, basic level, sufficient level and high level) were determined for each student.

Students performed different types of tasks. The levels of formation of methods of mental actions and mathematical knowledge and skills were determined by the devised criteria.

To conduct the study, freshmen were divided into two groups: a control group and an experimental group. In the control group, teaching was carried out in the traditional way (according to the discipline program). Study of higher mathematics in the experimental group was based on such approaches: mastering of the content of the mathematical subjects takes place as a result of formation of skills and practice of performing the operations (classification, generalization, establishment of the regularity, analogy) and information processing; student's activity is based on the algorithmization of the education process and activation of logic-algorithmic thinking components; activity, aimed at the development of the algorithmic schemes, used for problems solution.

Different types of tasks were used in the survey of students and the formation of selected methods of mental actions: problems with complete solutions, problems with simulation of the situation, problems with the choice of the answer.

The fourth stage. Summing up the experiment.

\section{Results}

The formative stage of the experiment covered 135 students of the experimental group and 140 students of the control group.

In accordance with the task of the study, we formulated a hypothesis: if students of technical universities develop selected operational components of algorithmic thinking, it will increase the level of formation of mathematical knowledge and skills.

First we found out if the students understood the content of the operations (analogy, classification, generalization, regularities; Tables 1,2)

Table 1. Testing results of the understanding of the operation component

\begin{tabular}{|c|c|c|c|c|}
\hline \multirow{2}{*}{$\begin{array}{c}\text { Number of } \\
\text { students, who } \\
\text { understand } \\
\text { the content of } \\
\text { the technique } \\
\text { in } \%\end{array}$} & Analogy & $\begin{array}{c}\text { Classifica } \\
\text { tion }\end{array}$ & $\begin{array}{c}\text { Regulariti } \\
\text { es }\end{array}$ & $\begin{array}{c}\text { Generaliz } \\
\text { ation }\end{array}$ \\
\cline { 2 - 5 } & $45,6 \%$ & $21,9 \%$ & $45,6 \%$ & $18,4 \%$ \\
\hline
\end{tabular}

Table 2. Testing results of the understanding of the operation component

\begin{tabular}{|c|c|c|c|c|c|c|}
\hline \multirow{3}{*}{$\begin{array}{c}\text { Number of } \\
\text { students, } \\
\text { who } \\
\text { understand } \\
\text { the content } \\
\text { of the } \\
\text { technique } \\
\text { in } \%\end{array}$} & \multirow[b]{2}{*}{$\begin{array}{l}\text { Students } \\
\text { understand the } \\
\text { content of «4 } \\
\text { techniques» }\end{array}$} & \multirow[b]{2}{*}{$\begin{array}{l}\text { Students } \\
\text { understand the } \\
\text { content of «3 } \\
\text { techniques » }\end{array}$} & \multirow[b]{2}{*}{$\begin{array}{l}\text { Students } \\
\text { understand the } \\
\text { content of «2 } \\
\text { techniques » }\end{array}$} & \multirow[b]{2}{*}{$\begin{array}{c}\text { Students } \\
\text { understand the } \\
\text { content of «1 } \\
\text { technique» }\end{array}$} & \multicolumn{2}{|c|}{ Did not select any operational component } \\
\hline & & & & & $\begin{array}{l}\text { As they did not } \\
\text { understand the } \\
\text { content of these } \\
\text { components }\end{array}$ & $\begin{array}{l}\text { As they did not } \\
\text { understand how they } \\
\text { could be used for the } \\
\text { realization of the task }\end{array}$ \\
\hline & $7 \%$ & $4,4 \%$ & $17,5 \%$ & $58,9 \%$ & $2,6 \%$ & $9,6 \%$ \\
\hline
\end{tabular}


At the second stage of the research the formation level of the operational components of the algorithmic thinking was verified. For this purpose we performed testing, containing five blocks of questions.

First block (logical thinking). As the basis of the developed algorithmic thinking is the developed and knowledgeable logical thinking, then the first block of questions contained most of the testing tasks.

The test contained 30 questions. Each question comprised the condition and three consequences. Only one of three consequences is correct. Students had to select the correct logic consequences from the incorrect ones. The test did not require special mathematic knowledge.

Series of the tests of the second, third, fourth and fifth blocks determines the level of development of the intellectual actions (establishment of the analogies, classification, generalization, search of the regularities) on the material of physical-mathematical, natural, social and humanitarian cycle.

Second block (establishment of the analogy). Three words are given. The first and the second words are s related by the content. From four words you should choose the word, that is related by the content with the third as the first is related with the second.

Third block (classification of the objects by essential features). Four words are given, three of these words are connected by the common feature. Find the word that does not have such feature.

Fourth block (generalization).

Pairs of words are given. Choose from four variants that one which expresses the most important for both words features. Solving the problem of the given block the students are to determine the abstract properties of the objects by means of the interrelations these objects enter.

Fifth block (establishing of the regularity). Numbers in each row are located according to a certain rule. Students must understand this regularity and find a number that continues this numerical row. For the solution of the given type of tasks the operations of the comparison i.e., analytical-synthetic activity, are presented. However, the analysis, carried out above, shows that in the given case we deal with the highest form of generalization, performed on the base of the analysis and is expressed by the definition of the general in a number of objects by means of comparison.
The test results are summarized in Table 3.

Table 3. Testing results of the formation of the operation components

\begin{tabular}{|c|c|c|c|c|}
\hline \multirow{2}{*}{} & \multicolumn{4}{|c|}{ Level of the operation components development } \\
\cline { 2 - 5 } & Low & Basic & Sufficient & High \\
\hline $\begin{array}{c}\text { Logical } \\
\text { thinking }\end{array}$ & $14,7 \%$ & $23,5 \%$ & $41,2 \%$ & $20,6 \%$ \\
\hline Analogy & $29,4 \%$ & $23,5 \%$ & $22 \%$ & $25,1 \%$ \\
\hline Classification & $28,5 \%$ & $31 \%$ & $22,2 \%$ & $18,3 \%$ \\
\hline Generalization & $23,5 \%$ & $39,7 \%$ & $20,6 \%$ & $16,2 \%$ \\
\hline Regularities & $17,6 \%$ & $23,5 \%$ & $17,6 \%$ & $41,3 \%$ \\
\hline Total & 22,8 & 28,2 & 24,7 & 24,3 \\
\hline
\end{tabular}

Obtaining of the data by the index "mathematical knowledge and skills" of the cognitive criterion was carried out by means of the test work.

Taking into account the fact that the first-year students did not study higher mathematics, the level of their knowledge of this subject was evaluated by means of the secondary school course test.

The text of the test work contained the problems of the four levels, the answers required the knowledge of the definitions of the mathematical notions, formulas, graphs, images of the mathematical figures, etc. The performance of the students in theoretical training was determined by the correct answers.

The results of the test work are shown in Table 4.

Table 4. Results of the diagnostic test work in the control and experimental groups regarding the level of mathematical knowledge cognitive and skills by criterion at the beginning of the experiment (by cognitive criterion)

\begin{tabular}{|c|c|c|c|c|}
\hline $\begin{array}{c}\text { Formation } \\
\text { levels of } \\
\text { mathematical } \\
\text { knowledge } \\
\text { and skills }\end{array}$ & \multicolumn{2}{|c|}{ Experimental group } & \multicolumn{2}{c|}{ Control group } \\
\cline { 2 - 5 } & $\%$ & Quantity & $\%$ & Quantity \\
\hline Low level & $11,9 \%$ & 17 & $8,8 \%$ & 12 \\
\hline Basic level & $45,3 \%$ & 61 & $47,6 \%$ & 66 \\
\hline $\begin{array}{c}\text { Sufficient } \\
\text { level }\end{array}$ & $31,4 \%$ & 42 & $27,4 \%$ & 39 \\
\hline High level & $11,4 \%$ & 15 & $16,2 \%$ & 23 \\
\hline Total & $\mathbf{1 0 0}$ & $\mathbf{1 3 5}$ & $\mathbf{1 0 0}$ & $\mathbf{1 4 0}$ \\
\hline
\end{tabular}

Table 5. Calculation of $\lambda$-Kolmogorov-Smirnov test

\begin{tabular}{|c|c|c|c|c|c|c|c|}
\hline \multirow{2}{*}{ Levels } & \multicolumn{2}{|c|}{ Empirical frequencies } & \multicolumn{2}{c|}{$\begin{array}{c}\text { Empirical relative } \\
\text { frequencies }\end{array}$} & \multicolumn{2}{c|}{$\begin{array}{c}\text { Accumulated empirical } \\
\text { relative frequencies }\end{array}$} & \multicolumn{2}{c|}{$\begin{array}{c}\text { Absolute value of the } \\
\text { difference }\end{array}$} \\
\cline { 2 - 8 } & $F_{e}$ & $F_{\kappa}$ & $f_{e}$ & $f_{\kappa}$ & $\sum f_{e}$ & $\sum f_{\kappa}$ & $d=\left|\sum f_{e}-\sum f_{\kappa}\right|$ \\
\hline Low & 17 & 12 & 0,119 & 0,088 & 0,119 & 0,088 & 0,031 \\
\hline Basic & 61 & 66 & 0,453 & 0,476 & 0,572 & 0,564 & 0,008 \\
\hline Sufficient & 42 & 39 & 0,314 & 0,274 & 0,886 & 0,838 & 0,048 \\
\hline High & 15 & 23 & 0,114 & 0,162 & 1,000 & 1,000 & 0 \\
\hline Total & 135 & 140 & 1,000 & 1,000 & & & \\
\hline
\end{tabular}


For the determination of the samples homogeneity we used $\lambda$ Kolmogorov-Smirnov test. Two hypotheses were formulated: $\mathrm{H}_{0}$ - distributions of the students according to the level of mathematical knowledge and skills formation in the control and experimental groups by the cognitive criterion are the same; $\mathrm{H}_{1}$ - distributions of the students according to the level of mathematical knowledge and skills formation in the control and experimental groups by cognitive criterion differ. Calculation of $\lambda$ - Kolmogorov-Smirnov test is presented in the Table 5 .

Maximum discrepancy between the accumulated relative frequencies is $d_{\max }=0,048$, then

$$
\lambda_{\text {eun }}=0,048 \cdot \sqrt{\frac{135 \cdot 140}{135+140}} \approx 0,3979
$$

According to statistical tables (Sidorenko, 2004) the level of statistical significance $\lambda_{e n n}=0,3979$ was determined and $\rho=0,998$ was obtained.

Having constructed the significance axis, where critical values $\lambda_{0,05}=1,36$ and $\lambda_{0,01}=1,63$ are shown which correspond to the levels of statistical significance $\rho=0,05$ and $\rho=0,01$, generally accepted in psychological-pedagogical studies, we obtained graphic image ( Figure1).

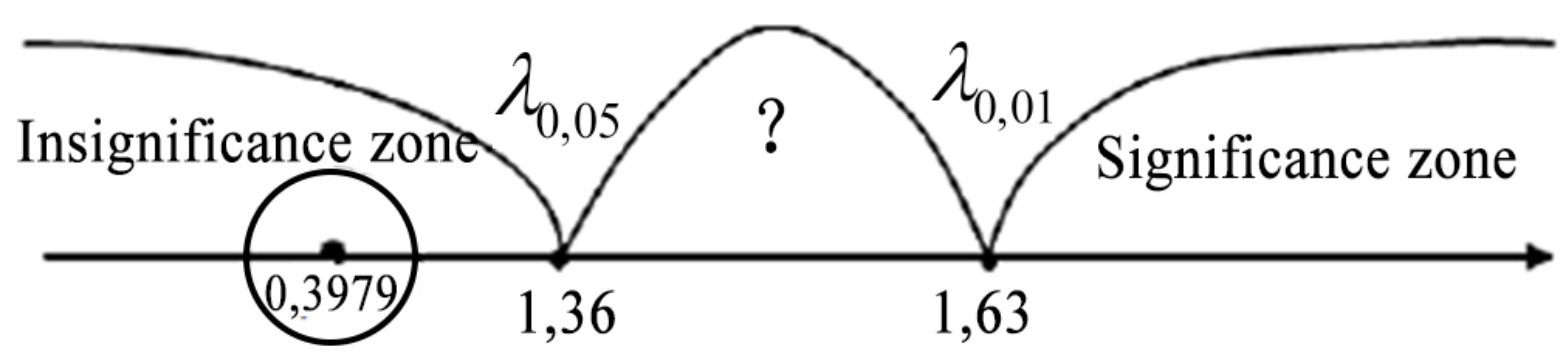

Figure 1. Application of Kolmogorov-Smirnov test for the verification of the homogeneity in the process of the formation experiment of the students' samples

Table 6. Distribution of the students by the formation levels of mathematical knowledge and skills by cognitive criterion at the beginning and after the completion of the experiment

\begin{tabular}{|c|c|c|c|c|c|c|c|c|c|}
\hline \multirow{3}{*}{ Criterion } & \multirow{3}{*}{$\begin{array}{l}\text { Samples } \\
\text { Type }\end{array}$} & \multicolumn{8}{|c|}{ Formation levels of the cognitive criterion index } \\
\hline & & \multicolumn{2}{|c|}{ Low } & \multicolumn{2}{|c|}{ Basic } & \multicolumn{2}{|c|}{ Sufficient } & \multicolumn{2}{|c|}{ High } \\
\hline & & Before & After & Before & After & Before & After & Before & After \\
\hline \multirow{4}{*}{ Cognitive } & EG & 17 & 8 & 61 & 39 & 42 & 65 & 15 & 23 \\
\hline & 135 & $11,9 \%$ & $5,9 \%$ & $45,3 \%$ & $28,9 \%$ & $31,4 \%$ & $48,1 \%$ & $11,4 \%$ & $17,1 \%$ \\
\hline & $\mathrm{CG}$ & 12 & 10 & 66 & 62 & 39 & 43 & 23 & 25 \\
\hline & 140 & $8,8 \%$ & $7,2 \%$ & $47,6 \%$ & $44,3 \%$ & $27,4 \%$ & $30,7 \%$ & $16,2 \%$ & $17,8 \%$ \\
\hline
\end{tabular}

The determined value $\lambda_{e n n}=0,397$, as it is seen from Figure 1, is located on the left from the critical value $\lambda_{0,05}=1,36$, i.e., in the insignificance zone. As $\lambda_{e u n}<\lambda_{k p}$, then the hypothesis $\mathrm{H}_{0}$ regarding the homogeneity of the students distribution in our samples according to the formation levels of the mathematical knowledge and skills by cognitive criterion at the beginning of the experiment is confirmed. The samples are equivalent and can be used to determine the efficiency of the implementation of the developed teaching methods of higher mathematics at Technical Universities.

After the completion of the formation stage of the experiment second control testing of the students by the indices of cognitive criterion of mathematical training was carried out.
Test work contained tasks of the higher mathematics course, corresponding to four levels of complexity.

For the sake of convenience of changes comparison in the distributions of the students by the levels of the indices formation of cognitive criterion the results of testing will be located at the beginning and at the end of the formation stage of the experiment in the Table 6 .

As it is seen in Table 6, changes occurred in the distributions of the students of the control and experimental samples. Considerable changes occurred in the students of the experimental sample by the basic, sufficient and high formation levels of mathematics knowledge and skills.

To substantiate the reliability of the results we use the $\varphi^{*}$ - Fisher angular transformation in combination with the $\lambda$-Kolmogorov-Smirnov criterion (Sidorenko, 2004). 
As $\lambda$-Kolmogorov-Smirnov criterion enables to find the point of maximum difference between the samples, then the combination of $\varphi^{*}$ criterion and $\lambda$ -Kolmogorov-Smirnov criterion gives the valid result. The obtained data give grounds to think that, the "effect is present" if by the cognitive criterion mathematical knowledge and skills correspond to sufficient and high levels and "the effect is absent", when the level of mathematical knowledge and skills is at the initial and middle levels.

Possessing the obtained data, we constructed the table for the calculation of $\varphi^{*}$ - criterion-- Fisher angular transformation (Table 7).

Table 7. Data for calculation of Fisher criterion $\varphi^{*}$

\begin{tabular}{|c|c|c|c|c|c|}
\hline \multirow{2}{*}{ Groups } & \multicolumn{2}{|c|}{$\begin{array}{c}\text { "effect is absent" } \\
\text { (low and basic level } \\
\text { of knowledge after } \\
\text { the experiment) }\end{array}$} & $\begin{array}{c}\text { "effect is present" } \\
\text { (sufficient and high } \\
\text { level of knowledge } \\
\text { after the } \\
\text { experiment }\end{array}$ & Total \\
\cline { 2 - 6 } & persons & $\%$ & persons & $\%$ & persons \\
\hline $\begin{array}{c}\text { Experim } \\
\text { ental }\end{array}$ & 47 & 34,8 & 88 & 65,2 & 135 \\
\hline Control & 72 & 51,4 & 68 & 48,6 & 140 \\
\hline
\end{tabular}

Further two hypotheses were formulated:

$\mathrm{H}_{0}$ - share of persons who, by the cognitive criterion achieved sufficient and high levels in the experimental group is not greater than in the control group;

$\mathrm{H}_{1}$ - share of persons who, by the cognitive criterion achieved the sufficient and high levels in the experimental group is greater than in the control group. According to the statistical tables, $\varphi_{1}$ and $\varphi_{2}$ were determined, that correspond to the percentage fractions of the "effect" presence in each group: $\varphi_{1}(65,2 \%)=1,88$; $\varphi_{2}(48,6 \%)=1,543$.

Further, the empiric value of the $\varphi^{*}$ - criterion:

$$
\varphi_{\text {eun }}^{*}=(1,88-1,543) \cdot \sqrt{\frac{135 \cdot 140}{135+140}} \approx 2,794
$$

Significance axis is shown in Figure 2.

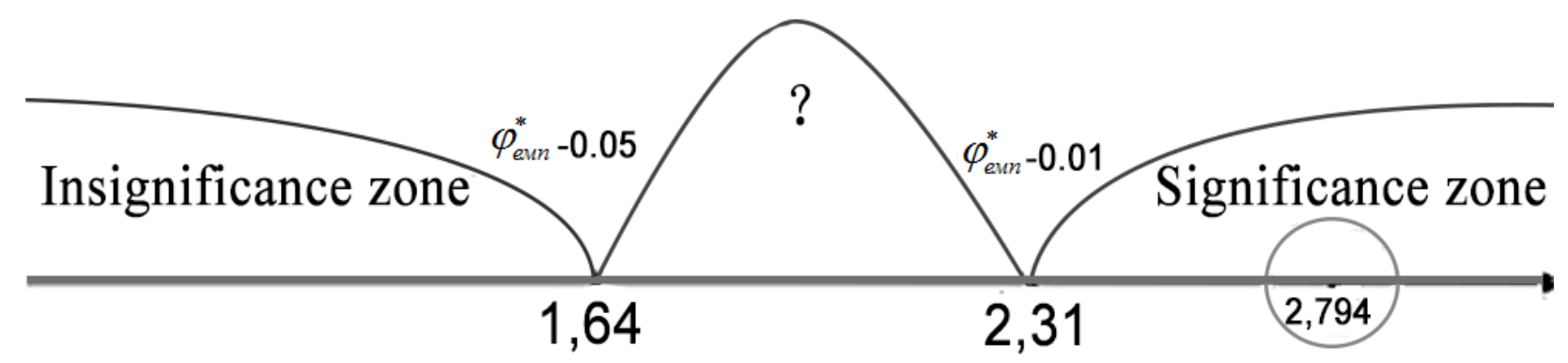

Figure 2. Significance axis 
Calculated value $\varphi_{\text {eun }}^{*}=2,794$ is in the significance zone. Level of the corresponding statistical significance $\rho \leq 0,01$. Based on this, the null hypothesis was rejected and the alternative hypothesis $\mathrm{H} 1$ was accepted - the proportion of individuals in whom the cognitive component is formed at sufficient and high levels in the experimental group is greater than in the control group.

\section{Discussion}

\subsection{Criteria for Controlling the Level of Formation of Mental Actions}

The following criteria were used to control the level of formation of selected methods of mental actions in students: low level (formal knowledge of definitions, elements of theory; the technique is used intuitively; there is no logical thinking.); basic level (they know the definition, structure of technique, examples of application of technique; make the plan of action; logical thinking is developed weakly.); sufficient level (they are able to choose the technique and substantiate its use; make mistakes in unusual situations.); high level (they are able to apply the technique independently and without errors in most cases). directed at general readers in no more than 20 words.

\subsection{Criteria for Controlling the Level of Formation of Mathematical Knowledge and Skills}

The following criteria were used to control the level of formation of selected methods of mental actions in students: low level (weakly expressed mathematical skills and abilities, cannot solve mathematical tasks even by sample); basic level (they solve problems according to the sample; use familiar methods of mathematical calculations; the student performs mathematical modeling with some difficulty and with outside assistance); sufficient level (independently solve mathematical problems; show the ability to use computer technology); high level (have the skills to use mathematical methods and computer technology to solve educational mathematical problems).

\subsection{Analysis of the Results}

According to the results presented in tables 1,2 and 3, we see that most freshmen have a basic level of development of selected operational components; the most difficult for students is to work with abstract images and draw logical conclusions.

If we analyze in more detail, then: $23 \%$ of students use the techniques of mental actions unconsciously or intuitively, and in most cases there is no logical thinking; $28 \%$ of students are aware of the content of the technique through its verbal description, generalization and compilation of an indicative basis for its use, while logical thinking is developed not enough; $25 \%$ of students use the technique independently, they have well-developed logical thinking, but students can make mistakes in unusual situations; $24 \%$ of students can comprehensively apply various techniques of algorithmic thinking, able to consciously control their mental activity in the process of working on the task and think logically.

The generalized data presented in Table 10 show that in the experimental groups the proportion of students whose knowledge in higher mathematics reached "sufficient" and "high" level after applying the proposed method increased (43\% - before, $65 \%$ - after).

\section{Conclusions}

The results of the study showed that: the problem of algorithmic thinking formation of schoolchildren and students is generally recognized in the world; only a small number of students are able to apply the operational components of algorithmic thinking comprehensively in a holistic process of solving various problems, manage their mental activity consciously and think logically; if students develop techniques of mental actions, which are the main components of algorithmic thinking (the ability to generalize, classify, draw analogies, establish patterns and reason logically), it contributes to better learning of higher mathematics.

\section{REFERENCES}

[1] Standart vyshchoi osvity [Standard of Higher Education]. Online available from: https://mon.gov.ua/storage/app/medi a/vishcha-osvita/zatverdzeni\%20standarty/

2019/06/25/141-elektroenergetika-elektrotekhnika-ta-elektr omekhanika- magistr.pdf.

[2] Sidorenko, E.V. (2004). Metody matematicheskoj obrabotki $v$ psihologii [Methods of Mathematical Processing in Psychology], Sankt-Peterburg: OOO „Rech"”.

[3] Gejn, A.G. \& Junerman, N. A. (2003). Zadachnik-praktikum po informatike $i$ informacionnym tehnologijam [Workshop Problem Book on Computer Science and Information Technology], Moskva: Prosveshhenie.

[4] Nikolaeva, T.V. (2020). Vazhnost' algoritmov v nashej zhizni [The importance of algorithms in our lives.], Pedagogika segodnja: problemy i reshenija: materialy VI Mezhdunarodnoj nauchnoj konferencii (g. Sankt-Peterburg, aprel' 2020 g.). - Sankt-Peterburg: Svoe izdatel'stvo, 56-57. Online available from: https://moluch.ru/conf/ped/archive/3 $64 / 15718 /$

[5] Jurkov, V.Ju. Osnovy sistemy razvitija i kontrolja vizual'no-algoritmicheskogo myshlenija [Fundamentals of the system for the development and control of visual algorithmic thinking]. Sovremennoe obrazovanie,,1,72-84. Online available from: DOI: $10.25136 / 2409-8736.2019 .1 .2$ 6453

[6] Voloshynov, S. A. (2012). Alhorytmichna pidhotovka maibutnikh sudnovodiiv z systemoiu vizualnoi pidtrymky $\mathrm{v}$ umovakh informatsiino-komunikatsiinoho pedahohichnoho 
seredovyshcha: dys....kand. ped. nauk. 13.00.04 [Algorithmic training of future drivers with a system of visual support in the information and communication pedagogical environment: dis....cand. ped. sciences: 13.00.04], Kherson.

[7] Ershov, A.P., Zvenigorodskij, G.A. \& Pervin, Ju.A. (1979). Shkol'naja informatika: koncepcii, sostojanija, perspektivy [School informatics: concepts, states, perspectives], Preprint, 152 VC SO AN SSSR, Novosibirsk.

[8] Gubina, T. N. (2016). Metodicheskie priemy razvitija algoritmicheskogo myshlenija budushhego uchitelja informatiki [Methodical methods of development of algorithmic thinking of the future teacher of computer science]. Online available from: http://ceur-ws.org/Vol-176 1/paper01.pdf

[9] Smetanina, L. S. (2010). Pedahohichni umovy orhanizatsii alhorytmichnoi diialnosti maibutnikh uchyteliv suspilno-humanitarnoho napriamu vyshcha: dys....kand. ped. nauk: 13.00.04 [Pedagogical conditions for the organization of algorithmic activities of future teachers of social sciences and humanities : dis....cand. ped. sciences: 13.00.04], Odessa.

[10] Milkova, E. (2014). Development of algorithmic thinking and imagination: base of programming skills. Online availa from:

https://www.researchgate.net/publication/260383669_Deve lopment_of_Algorithmic_Thinking and_Imagination_ of programming_skills

[11] Gal-Ezer, J. \& Zwas, G. (1996). A Note on Algorithmic vs. Instrumental Thinking in Mathematics Education, in preparation.

[12] Altuhova, S. O. \& Smirnov, I. N. (2016). Formirovanie algoritmicheskogo myshlenija studentov VUZa v processe professional'no pedagogicheskoj podgotovki [ Formation of Algorithmic Thinking of University Students in the Process of Professional Pedagogical Training]. Online available from:https://cyberleninka.ru/article/v/formirovaniealgoritmicheskogo-myshleniya-studentovvuza-v-protsesseprofessionalnopedagogicheskoy-podgotov ki.

[13] Kalitina, V. V., Pushkareva, T. P. \& Stepanova, T. A. (2015). Razvitie algoritmicheskogo stilja myshlenija pri obuchenii programmirovaniju $v$ vuze. Teoreticheskie $i$ prakticheskie aspekty psihologii $i$ pedagogiki [Development of an Algorithmic Style of Thinking in Teaching Programming at a University. Theoretical and practical aspects of psychology and pedagogy], Ufa, Russia: Aeterna.

[14] Pushkareva, T. P., Stepanova, T. A. \& Kalitina, V. V. (2017). Didakticheskie sredstva razvitija algoritmicheskogo stilja myshlenija studentov [Didactic Means of Developing Students' Algorithmic Thinking Style]. Obrazovanie i nauka, Vol. 19, 9, 126-143.

[15] Spirin, O. M. \& Vakaliuk, T. A. (2017). Kryterii doboru vidkrytykh web-opiientovanykh tekhnolohii navchannia osnov prohramuvannia maibutnikh uchyteliv informatyky. [Criteria for Selection of Open Web-oriented Technologies for Teaching the Basics of Programming to Future Computer Science Teachers]. Informatsiini tekhnolohii $i$ zasoby navchannia, Vol. 60, No. 4, 275-287.

[16] Vlasenko, K., Achkan, V., Chumak, O., Lovianova, I. \& Armash, T. (2020). Problem-Based Approach to Develop Creative Thinking in Students Majoring in Mathematics at Teacher Training Universities. Universal Journal of Educational Research, Vol. 8, No.7, 2853 - 2863. Online available from: DOI: 10.13189/ujer.2020.080712

[17] Hidayah, K. F., Hairun, S. Y. \& Sari, D. P. (2020). Design of PBL-Based Differential Calculus Module to Stimulate Students' Critical Thinking Skills. Universal Journal of Educational Research, Vol. 8, No. 7, 2778 - 2793. Online available from: DOI: 10.13189/ujer.2020.080705

[18] Bell, T., Rosamond, F. \& Casey, N. (2012). Computer science un plugged and related projects in math and computer science popularization. The Multivariate Algorithmic Revolution and Beyond, Springer-Verlag, LNCS 7370, 398-456.

[19] Hromkovič, J., Kohn, T., Komm, D. \& Serafni, G. (2016). Xamples of Algorithmic Thinking in Programming Education. Olympiads in Informatics, Vol. 10,111-124.

[20] Wilson, A. \& Golonka, S. (2013). Embodied Cognition is Not What you Think it is. Journal of Front Psychol, Vol. 4. Online available from:https://www.ncbi.nlm.nih.gov/pmc/a rticles/PMC3569617

[21] National Curriculum in England: Mathematics Programmes of Study (2016). Online available from: https://www.gov. uk/government/publications/national-curriculum-in-england -computing-programmes-ofstudy/national-curriculum-in-en gland-computing-programmes-of-study

[22] Ministere de l'Education Nationale (2016). Algorithmique et programmation (2016). Paris. Online available from: http://cache.media.eduscol.education.fr/file/Algorithmique et programmation/67/9/RA16 C4 MATH al gorithmique_et_programmation_N.D.D_5516̄79.pdf

[23] MEXT (Ministry of Education, Culture, Sport, Science, and Technology, Japan). Elementary school programming education guide (1st edition), 2018. Online available from: http://www.mext.go.jp/component/a_menu/education/micro _detail/__icsFiles/afieldfile/2018/03/30/14

[24] Australian Curriculum, Assessment and reporting Authority (ACARA), 2016. Online available from: https://www.acara. edu.au/reporting/national-report-on-schooling-in-australia/n ational-report-on-schooling-in-australia-2016

[25] Stephens, M. (2018). Embedding algorithmic thinking more clearly in the mathematics curriculum. School mathematics curriculum reforms: challenges, changes and opportunities. Online available from: https://www.researchgate.net/public ation/332012454_EMBEDDING_ALGORITHMIC_ THINKING MORE CLEARLY IN_THE_MĀTHEMATICS_CURRICULUM 